\title{
A Pattern of Tolerance Values Transformation by Parents Towards Early Childhood
}

\author{
Tjipto Sumadi *, Fauzi Abdillah and Asep Rudi Casmana \\ Department of Pancasila and Civics Education, Faculty of Social Science, Universitas Negeri Jakarta, DKI Jakarta, Indonesia
}

\section{OPEN ACCESS}

Edited by:

Cecep Darmawan,

Universitas Pendidikan Indonesia, Indonesia

Reviewed by: Jen Stacy,

California State University, Dominguez Hills, United States Juan Sánchez García, Miguel F. Martínez Normal School, Mexico

*Correspondence: Tjipto Sumadi tjsumadi@unj.ac.id

Specialty section: This article was submitted to Language, Culture and Diversity,

a section of the journal

Frontiers in Education

Received: 06 November 2020 Accepted: 10 September 2021

Published: 11 October 2021

Citation:

Sumadi T, Abdillah F and Casmana AR (2021) A Pattern of Tolerance Values Transformation by Parents Towards Early Childhood.

Front. Educ. 6:626680. doi: 10.3389/feduc.2021.626680
This study aims to discover a pattern of the transformation of tolerance values from parents to early childhood. The tolerance value in this day and age experiences some problems in the context of nationality. This can be seen from some parts of the area in Indonesia. For instance, in the traditional village of Cigugur, a life based on tolerance is experienced in the community. This study focused on the Cigugur community's pattern of applying tolerance values in family and community life. This study uses a qualitative method to undertake the study. Observations and in-depth interviews were used to carry out the data collection, and then it was verified and validated through four stages: member check, audit trial, triangulation, and expert opinion. It can be concluded that the pattern of the transformation of tolerance values from parents to early childhood could be transformed through some stages; 1) making sense of kinship as an adhesive between followers of different religions, 2) conveying religious teachings towards differences, not to be contested but to be respected and admired, 3) avoiding the content of particular political interests, 4) having a sense compassion for each other, and 5) having tepo seliro (respect) for each other.

Keywords: values transformation, Tolerance, early childhood, Cigugur, indigenous values

\section{INTRODUCTION}

Tolerance is considered to be an important characteristic in Indonesia. The reason is that people are diverse, in terms of ethnicity, religion, languages, and others. One of the results of intolerance is that people have conflict with one another (Kwok, 2004). As such, the characteristic of tolerance is needed by a diverse country in which there are many differences. The word tolerance has a wide range of meanings and definitions. Tolerance comes from the Latin word, "tolerate" (Lehtonen, 2019). It means to allow something patiently. The broad definition of tolerance is a human behavior or attitude that does not deviate from the rules, where someone respects or appreciates every action taken by others. Tolerance can also mean mutual respect between groups or between individuals both within society and in other spheres. An attitude of tolerance can avoid discrimination, even though there are many different groups in a community (Kwok, 2004). Tolerance occurs because of the desire to avoid disputes that are mutually beneficial to both parties. Disagreement is essential for tolerance because, without it, tolerance is not needed. So, it can be understood that tolerance supports neutrality and prohibits judgment on others because all views are considered equally valid (Beckwith and Koukl, 1998). In previous studies, the authors positioned tolerance as requiring a plurality of values because it departs from selfcontrol in responding to disagreements with others (Sumadi et al., 2019). Therefore, in a bold definition, tolerance is a human attitude to respect and appreciate each other, both between individuals and between groups. The attitude of tolerance is highly respected in the archipelago 
until it is stated in state law. Tolerance values should be taught as early as possible. In this case, when children are young would be one of the best times for transforming tolerance values.

Early childhood is a stage of development of young children at the age of $0-8$ years. According to Beichler and Snowman Hong, Yonghee, 2003) early childhood is a child aged between 3-6 years. While the nature of early childhood (Maksum, 2015) is unique to the individual, there is a pattern of growth and development in the physical, cognitive, socio-emotional, creativity, language, and communication aspects specifically in accordance with the stages that the child is going through. From various definitions, researchers conclude that early childhood is children aged $0-8$ years who are in the stage of growth and development, both physically and mentally.

Early childhood is often referred to as the "golden age". At this time, potentially almost all children experience a sensitive period in which to grow and develop rapidly and greatly. The development of each child is not the same because each individual has a different development. During this age, children in early childhood need social and emotional development, requiring parents at home and teachers at schools to insert positive inputs for them (Alzyoud, et al., 2016). The social and emotional development means young children need support from parents emotionally. They need to be accompanied and directed in all activities they complete. For example, when young children see some other people who behave differently, parents need to say some positive word to them. Then, it will encourage young children to always think positively. In relation to tolerance, the social and emotional development can help young children to have a positive thinking outlook towards some other people who behave differently.

As they are in the golden age, the tolerance values really need to be integrated during learning. In the school, teachers need to tell stories about people who are tolerant towards difference while parents at home should also show positive examples of people who behave with tolerance towards the differences between humans. One way to integrate tolerance in the golden age is for parents to give some advice about life experiences and other people's experiences. Therefore, the tolerance values should be integrated during this age.

Since tolerance has been considered to be very important, teaching tolerance must be started by early childhood. Teaching tolerance is considered a long-term plan, so that parents need to know how to educate children about tolerance values (Lintner, 2005). In Indonesia, tolerance is essential since this country is plural and philosophical in diversity. One aspect of the diversity in Indonesia can be seen from the religion. Over more than 250.000.000 people in the Indonesian population, the majority of Indonesians are Muslim, Catholic, Protestant, Hindu, Buddhist, and Confucian (Wiryawan, 2016). However, there are some beliefs which exist apart from these. When it comes to the Cigugur community, there is a wide range of difference in terms of religion, even within families. For instance, in a family, a father and mother may come from different religions. The father may be Muslim, and the mother may be catholic. In addition, sometimes, the son and daughter are also of different beliefs. They are given a freedom to choose what kind of religion to follow by their parents (Musyafiq, 2019). These sort of circumstances are interesting to some other communities as no one community has differences based on family.
The problems occurring in Cigugur community happen when transforming tolerance to their son and daughter, as every religion has different ways of teaching tolerance. In Islam, the source of educating tolerance comes from Al-Qur'an, while in Christianity it is from the Bible (Sumadi et al., 2019). Other religions also come from different holy books. For example, in Islam, the praying happens in five times a day, while in Christianity it is on Sundays. In Islam, people can go to the mosque to pray, while in Christianity, they go to the church. In other religions, they go to the temple for praying. In Cigugur, it can be seen that teaching tolerance is helping to navigate differences in each religion. Although there are differences based on ways of life, parents and teachers should discover the ways of transforming the knowledge of tolerance to early childhood.

In addition, a few years ago, there were some small religion communities in Cigugur who were expelled by the majority. It happened due to them belonging to no community. They were newcomers to the Cigugur community, and the people did not like that new community. The newcomers were Christians trying to stay in Cigugur society. Since the majority of Cigugur society was Muslim, they did not want any other community who were of a different religion from them get into Cigugur. The local community argued that if the newcomers who were different religions started to stay and join them, there would be a spread of new religion for the locals. At that time, the number of new communities coming to Cigugur were more than 100 people. Although the locals were trying to decline the newcomers, the local leader was trying to initiate a mediation and communication between the local community and the newcomers. Starting from then, the Cigugur community became more diverse and welcoming to newcomers. The traditional value of tolerance taught by parents in the Cigugur community to young children is interesting. They had a strategic position in preparing and building the next generation's character in its environment (Nurasiah et al., 2019). Therefore, it is interesting to study how the implementation of tolerance occurs in Cigugur. It is also essential to describe what values are instilled by parents in young children so that later they can behave tolerantly in society (Lintner, 2005).

Creating tolerance as a value is not considered easy (Lintner, 2005). It takes time and it should be started from an early age. Although there a lot of ways of teaching tolerance to people, it is importance to educate young children about the core value of tolerance. In Indonesia, there are some varieties of teaching tolerance that can be undertaken by teachers and students. The research carried out by Maksum (2015) revealed that teaching tolerance or transforming tolerance values can be started from the school. The school mentioned by Maksum is an Islamic Boarding School (Pesantren). In Islamic school, such as modern boarding schools and salaf, the teachings of Islam were understood and actualized as inclusive, friendly, not rigid, moderate, and nuanced differences, as well as implementing multicultural values. This research by Maksum shows that in Salafi, pesantren education implements tolerance learning through a multicultural approach by respecting differences in beliefs between religious communities. In addition, multicultural education plays an important role in teaching tolerance to students. However, this model of multicultural education is 
only taught by Islamic ways, so other beliefs cannot learn from this school.

In general, multicultural education is being taught in each school in Indonesia (Maksum, 2015). However, it is integrated towards some other subjects, such as social studies, civic education, history education, and other related subjects (Maksum, 2015). In Islamic boarding school, the multicultural education is not only taught as a theory in the classroom, but also they are living in a very diverse environment. Firstly, the Islamic boarding schools have some student housing, so that Muslim students can stay for years until the end of school. Secondly, students are living with three to four people in a room in which they are coming from different islands or difference provinces, so they are learning how to understand differences over the course of a long time. Finally, the tolerance values will appear after students finish their school since they can understand the differences. However, the concept of boarding school is not only in Islamic school, there are also other religious schools which are teaching tolerance values based on their own methods.

In addition, multicultural education is one of the ways of teaching tolerance in school as a formal subject. A study states that developing tolerance requires social, emotional maturity, and cognitive skills (Lehtonen, 2019). So, the position of adults is quite strategic in filling the development process. Parents and teachers work together to transform the value of tolerance into a complementary spirit (Tican, 2020). Teachers can develop tolerance through habituation (Mandayu, 2020), taught integrated with the teaching of English for the development of religious tolerance (Levina et al., 2016; Sumadi et al., 2019), through learning tahfid hadith (Musyafiq, 2019), history learning (Nurasiah et al., 2019; Utomo and Wasino, 2020) and science learning (Rahmayani Sari et al., 2017). To foster tolerance, empathy, and inclusiveness, it is essential to look at small discourses that significantly impact the responses that children produce (Huber, 2003; Maine and Čermáková, 2021).

Apart from teaching tolerance in school, there is another way of educating young people to have tolerance values. People can learn from the concept of a "shared house" in the community. The research carried out by Wasisto Raharjo Jati (2014), showed that the principle of a "shared house," in Indonesia, is the most important place in fostering students' tolerance. In the "shared house," students are treated as close family members in association with other academicians. The principle of "shared house" fosters the feeling of tolerance among fellow children of the nation, in the context of respecting differences in race, ethnicity, religion, and others. This shared house becomes a single identity for both men and women. The concept of the shared house is called "pedagogies of home" which was mentioned by Bernal (2001). She said that learning at home is obviously different from school. At home, students mostly have a conversation, and the difference can be seen directly while at school, as students learn the theory in the classroom. However, although the design of learning in school and at home are different, both school and home should support each other to educate the students about tolerance. In addition, religiosity is declared to be the instrumentation of the application of religious universality values such as tolerance and respect, and a sense of peace built to maintain the spirit of multiculturalism and strengthen brotherhood among students is realized. The concept of the shared house in a place where people are living with different religions can be considered to be a way of transforming tolerance for the people (Wiryawan, 2016). Therefore, teaching tolerance values is more likely focusing on character and the transmission in the home is different to how it is studied in the formal school. Therefore, the value of tolerance cannot be measured by exams or institutionalized practice.

Public school is also considered to be a way of transforming tolerance. There are several school subjects that can be for a way to educate the young generation to be tolerant, such as citizenship education, social studies, history, and other related subjects. The study undertaken by Agung Suharyanto (2013) revealed that Citizenship Education is one of the subjects that can foster an attitude of tolerance between students to interact with each other, respect, help, and help quite successfully. Through Citizenship Education learning that addresses tolerance, there is no longer any hostility or disagreement in the context of differences in the implementation of worship by their respective religions. The tolerance that students have is not only limited to knowledge but also in the practice of life. The module of citizenship education is not only theory in the classroom, but also something that students can practice in the classroom and community (Sumadi, 2017). Sometimes, teachers encourage students to create research that can be undertaken in a society which is different from theirs. In addition, Basri Endang (2015) argued that developing an attitude of tolerance and togetherness among students produced a conception that tolerance develops between diversity in various dimensions of life. It can create harmony and harmony in life, avoiding conflicts and social tensions and hostility between people in the community. This study also produced a conception of the importance of developing tolerance and togetherness through teachers' pedagogical engineering with diverse community settings. This similarity also occurs in the lifeorder in the school environment, with indicators that students interact with each other, learn to respect differences, and accept certain characteristics that occur in their environment.

The relevant studies mentioned above only focus on the students in school, but there is no research which focuses on teaching early childhood students in Indonesia, particularly in Cigugur society. In Cigugur, they have some traditions or ways of life that can be studied deeply about how they teach the young generation. As mentioned, Cigugur society has different beliefs within a family, so they have their own way of teaching tolerance for their children. The process of transforming values in the family has some characteristics, including a lack of requirements that must be completed, no examinations, no other institutions that provide assessments, no structured material to be presented, and no levels. Such is the looseness of the transformation of values in the family, making it interesting to study more deeply. These kind of values are taught by some parents in the Cigugur community.

This study will focus on how parents in Cigugur society transform tolerance values to their young children in Cigugur, Kuningan, West Java, Indonesia. The values of tolerance among people in Cigugur are very attached and are a belief taught to their children by the Cigugur community. So strong was the exercise of tolerance that the "vocation" voiced from houses of worship of 
different faiths was echoed alternately, without any noise. Likewise, with life in the household, under one roof, there are residents of different beliefs. There are families of parents, children, and daughters of different faiths, that still live in harmony and peace. These tolerance values are interesting to study carefully. What patterns of the transformation of tolerance values are carried out by the Cigugur community to create a comfortable and peaceful life. Specifically, research on the Cigugur community's life is still minimal; however, several similar studies have been conducted and can be stated as follows.

Research conducted by Monteflor et al. (2006) resulting in motivation in early childhood needs to be carried out continuously with a balanced and comprehensive approach. Providing motivation should be done together with the school. In addition, Schaller et al. (2007) conducted research stating that less-educated parents tend to put their children's education in a better place. In teaching attitudes to children, parents like this prefer to realize the implementation of attitude education through daily activities or real deeds in daily life. Value transformation activities are carried out through conversations, reading stories, and play activities that develop children's attitude skills. Through such activities, parents hope their children will be able to succeed and excel in academics. Gilliard and Moore (2007) conducted research. They stated that fostering attitudes related to the curriculum was effective communication between the school, parents, and the community about material relevant cultural values related to rituals, respect for children, respect for families, and important values in society (Tas and Minaz, 2019). All of these materials named Native American Indian Culture and were taught through programmed learning plans. Hong (2003), who conducted research, stated that children in early childhood need to be given more opportunities to overcome the problems they face by assisting as needed. Traditional puppets can mediate early childhood assistance through storytelling as part of character education (Halimah et al., 2020). Also, moral learning or attitudes need to be taught through processes that rely on rationality (not dogmatic), especially during school learning.

Based on the previous studies about educating children in early childhood to have tolerance values, parents also play a role in shaping character. Parents are the people who are communicating with the children all the time, meaning they will follow the advice from parents. In Cigugur society, there are a lot of unique ways of transforming tolerance values as this community has been created from diverse religions. Each religion has different way of teaching tolerance towards their children. Therefore, this research will focus on the transformation of tolerance values from parents to early childhood.

In terms of the above explanation, this study's research questions are: 1) how do the people of Cigugur Kuningan West Java transform tolerance values to their early childhood? 2) How do the activities of the transformation of tolerance values transfer from parents to early childhood?

\section{METHODS}

\section{Research Design}

This research is considered to be a study in education since the purpose is to see how parents in Cigugur community transfer
TABLE 1 | The characteristic of Participants Gender.

\begin{tabular}{llcc}
\hline No & Gender & Frequency & Percentage (\%) \\
\hline 1 & Male & 10 & 50 \\
2 & Female & 10 & 50 \\
Total & & 20 & 100 \\
\hline
\end{tabular}

their tolerance values towards children in early childhood. Therefore, it used a descriptive qualitative approach (Yin, 2017). A descriptive qualitative approach shows a description of how parents teach children about tolerance values. This study used qualitative methods and it also used focus group interviews and observations. The focus group interviews were done with some parents who have children in early childhood who discussed their way of teaching tolerance to their children. In addition, the practice of parents in transforming tolerance values was observed. In this study, it was explained and analyzed how the pattern of the transformation of tolerance values was carried out by parents to their children in Cigugur Kuningan, West Java. In this study also, the researcher acts as an instrument that plays an active role in digging for in-depth data information (in-depth interviews) from the informant. So that research continues to explore the focus and sub-focus of the material being studied, a research guide is made that outlines issues related to the pattern of the transformation of tolerance values from parents to early childhood. Data that was not predicted but had a comprehensive meaning and contributed to this research was explored through probing questions. The data that were obtained from the focus group interview and observation were analyzed using a qualitative approach.

\section{Participants}

The research about a pattern of tolerance values transformation by parents towards early childhood collaborated with ten parents or twenty people who have different backgrounds. Since there were some characteristics which should be required during this study, the purposive sampling technique was used to choose the participants. There were some criteria that needed to be applied for the participants, such as 1) parents should have at least one young children aged below 6 years old, 2) they come from different religions within the family. In order to have a great result, the focus group discussion was used three times with the duration of $130 \mathrm{~min}$ in each meeting. The details of the characteristics of participants shows in the table below.

Table 1 shows that both males and females made up 50\%, since they were parents who were participating in this study. Overall, all the parents who were participating in this study were considered to be a person coming from the Cigugur community.

Table 2 shows the characteristics of participants based on religion. Since the Cigugur community has a unique diversity of characteristics, it was required that participants of this research should also be diverse. At least, in a family, they needed to have different religion background. However, although there are different believers, Muslims made up the majority on this 
TABLE 2 | The characteristic of participants based on the religion.

\begin{tabular}{llcc}
\hline No & Religion & Frequency & Percentage (\%) \\
\hline 1 & Muslim & 10 & 50 \\
2 & Catholic & 3 & 15 \\
3 & Protestant & 2 & 10 \\
4 & Hindu & 2 & 10 \\
5 & Buddhist & 2 & 10 \\
6 & Confucian & 1 & 5 \\
Total & & 20 & 100
\end{tabular}

research. In addition, the diversity group in this research focused only on the religious difference. This is because there is no ethnic and linguistic diversity in Cigugur community. The majority of people living in Cigugur are of Sundanese ethnicity, speaking Sunda Language.

Having children is important in this study. However, it was required to have at least one child who is still in early childhood age. Table 3 show the characteristics of parents who have children in Cigugur community. The majority of parents only have one child, which makes up $50 \%$ of overall participants.

\section{Data Collection}

This study used a purposive sampling technique. Purposive sampling is one of the non-random sampling techniques where the researcher determines the sampling by determining special characteristics according to the research objectives in order to address the research problem. Based on the purposive sampling explanation, two things are crucial in using this sampling technique, namely non-random sampling and determining special characteristics according to the research objectives by the researcher. This study's most important requirement was that the parents should have at least one child and transform their tolerance values. There are at least two main requirements that participants should meet to take part in this study. Firstly, they should come from a diverse religion background. This means that the parents are of different religions, or the children have different beliefs. In addition, the parents should also have at least one child in early childhood, so that it is easy to understand how they transform the tolerance values to their children.

There are two methods of data collection in order to obtain information on how parents transform the tolerance values to their children, which are in-depth interview and observation. The in-depth interview plays an important role in gaining the data. It was focused on collecting the information about how parents in Cigugur transform the tolerance values to their young children, what kind of activities have been done by parents for transforming the value, and also how the young children applied the tolerance values that is transformed by their teacher. The number of informants involved in the interview were 15 with approximately $30 \mathrm{~min}$ in each interview. In addition, observation was used to gain an in-depth view of how parents transform their tolerance values to young children. The observation was taken place at parents' homes in Cigugur society. There were five parents who gave permission to be observed. The observation was happened for 15 days, so that the researcher spent 3 days in each parent's home to see how the
TABLE 3 | The characteristic of Participants based on the number of children.

\begin{tabular}{lccc}
\hline No & Number of children & Frequency & Percentage (\%) \\
\hline 1 & 1 & 10 & 50 \\
2 & $2-3$ & 4 & 20 \\
3 & $4-5$ & 4 & 20 \\
4 & $>5$ & 2 & 10 \\
Total & & 20 & 100 \\
\hline
\end{tabular}

transformation values were taught. The observation saw the communication between parents and young children, home teaching activities done by parents to the children, and how the tolerance values were applied. Therefore, the interview and observation supported the gaining of data for this research.

\section{Data Analysis}

In order to analyze the data, this study followed the analyzing technique by Yin (2017). Based in Yin (2017) there are three main ways of analyzing the data. These are pattern matching, explanation, and time series analysis. The analytical technique that is adopted in this study creates an explanation of the case in question. In this case, there are two main results that might be looked at to understand the way of parents transform tolerance values and the activities that might be done by parents to transform tolerance values.

After collecting the data, the results of the interview were transcribed, then it was analyzed and finally interpreted and triangulated based on the conversation during the interview. The use of the analytical concept developed by Yin (2017) makes the data more accurate and gives an abundance of explanations from the perspective of education. The analysis focuses on how parents in Cigugur society can transform their tolerance values for young children.

The data obtained from the interview and observation were transcribed by using some unique code so that they will be easy to analyze. The results of transcript were divided into ten transcripts since there were ten parents who were participating in this study. The results of the data were changed to the code such as PT1 (parents transcript 1), PT2 (parents transcript 2) and other code that was obtained from parents. After coding, it as easy to analyze the data using nVivo software qualitative analysis.

\section{FINDINGS}

(RQ1) How do the people of Cigugur Kuningan West Java transform tolerance values to their early childhood?

Tolerance can be called an attitude of openness between each person or group and mutual respect for differences in every human being. In this case, tolerance is not only limited to ethnicity, race, ethnicity, and religion, but also tolerance for gender, physicality, intellect, opinion and, for other things. However, although the concept of tolerance is accepting and respecting various things, tolerance does not always accept harmful attitudes or behavior from others. For example, bullying behavior, lying, and stealing are attitudes that cannot be tolerated. The main essence of tolerance is that children are 
TABLE 4 | example of tolerance that parents teach their children.

\begin{tabular}{|c|c|c|}
\hline No & Example of attitude & Benefits \\
\hline 1 & Show respect for others & Children can imitate positive things so indirectly tolerance can be conveyed \\
\hline 2 & Keeping the way of speaking & The style of speech becomes a positive thing when positive things are conveyed to children \\
\hline 3 & Pay attention to children's books, toys, and entertainment & Anything that becomes a tool for children to play with becomes the main medium in tolerance \\
\hline 4 & Discussing intolerance issues with children & By discussing intolerance, children can find out what cannot be done \\
\hline 5 & $\begin{array}{l}\text { Respond wisely to children's questions regarding } \\
\text { differences }\end{array}$ & Answering questions wisely can make children wiser when dealing with things that are intolerance \\
\hline 6 & Recognizing and respecting differences in the family & With the recognition of these differences, children will also imitate them \\
\hline 7 & Teaching the Limits of Tolerance & Although tolerance is respecting differences, children also need to be given boundaries \\
\hline 8 & Teach children to respect themselves & By teaching them how to respect themselves, they will try to be able to respect others too \\
\hline 9 & Involving children in diverse situations & $\begin{array}{l}\text { Involving children in diverse situations can make children more aware that Indonesia is a multicultural } \\
\text { country }\end{array}$ \\
\hline 10 & Learning other cultures and traditions with children & By studying other cultures well, this can make children understand the differences \\
\hline
\end{tabular}

given an educational process so that they can accept others as they are regardless of differences. Teaching tolerance to children can be done by giving some examples of attitudes to children, as taught by parents in Cigugur, Kuningan, West Java to their children.

Table 4 shows brief results from the interview with the parents in Cigugur, Kuningan, West Java about transforming tolerance values to the children. Although there are a wide range of methods for teaching tolerance, the study found that there ten methods for teaching the values to the young children. Overall, the examples of teaching tolerance focus on the attitude or character with which parents teach their young children at home.

Table 4 shows some of the values which can be seen from the attitude of parents in teaching tolerance. These ten values are for the general teaching of tolerance in Cigugur society. However, although there are ten attitudes, most of the values mentioned by parents focused on only four values. These are showing respect for others, paying attention to children's books, toys, and entertainment, recognizing and respecting differences in the family, and learning other cultures and traditions with children. The four values which were focused on in this study were always mentioned by the parents during the interview. In addition, the values which were mentioned are related to other previous studies.

The first values which parents teach to their young children is "showing respect for others and keeping the way of speaking". In this character, showing respect means parents give a positive attitude when they communicate or talk with other people in front of young children, while keeping the way of speaking means showing the use of positive words by parents. This is utterly important since young children always try to follow what parents do and say. For example, when parents meet with a person who is older, they use a positive word and polite language. When their child sees what parents do, they will automatically follow and put it on their mind.

"When I meet with a person who is older than me, I always speak with a positive word and polite language, so that my young children can follow the way I behave to others" (Interview, AM).

Speaking politely to others shows a good effort which parents show for transferring the tolerance values to the children. The way parents speak and behave to the others will be followed and imitated by the young children. This is because the people who are teaching the young children most throughout their lives are parents. On the other hand, when parents show a negative words or negative behavior in front of the children, they will follow as well. For example, when parents have a conflict and use a negative word for one another and young children see, it will come to their mind and will be memorized on their brain. Similar results can be seen from the study undertaken by Rapp and Freitag (2015) who revealed that educating in early childhood should be started by giving a real example. Rapp and Freitag argue that parents are the first people in the world who are seen by the young children. In addition, children spend a lot of time with their parents, as such parents should give some good examples for their children. When an appropriate example has been seen by children, they will follow.

In addition, paying attention to children's book, toys, and entertainment as well as discussing tolerance issues with young children have a good impact for teaching tolerance values. The book that is always read will be integrated to the mindset of the young children. In this case, children are trying to learn reading, and parents read the book aloud before sleeping in the night. Then, parents should show a positive book that can motivate young children not to be intolerant.

"Before my son sleeping in the night, I always give a book about the story of animals. The title of the book is about monkey and turtle. It shows the character's respect towards other animals. The story of animals is loved by my son, so that it is suitable to show an example of positive attitude to the young children" (YM, Interview).

"My children really like watching movies from YouTube. I am trying to ban some contents and filter it, so that my children can see the videos which show a positive attitude about tolerance" (TU, interview).

"After watching a YouTube video and reading a book, sometimes my young children ask me a lot of questions about the story that I told and the movie that he saw. I am trying to answer the question with giving an example and positive attitude, so that it makes him understand the importance of tolerance and character" (TIU, Interview). 


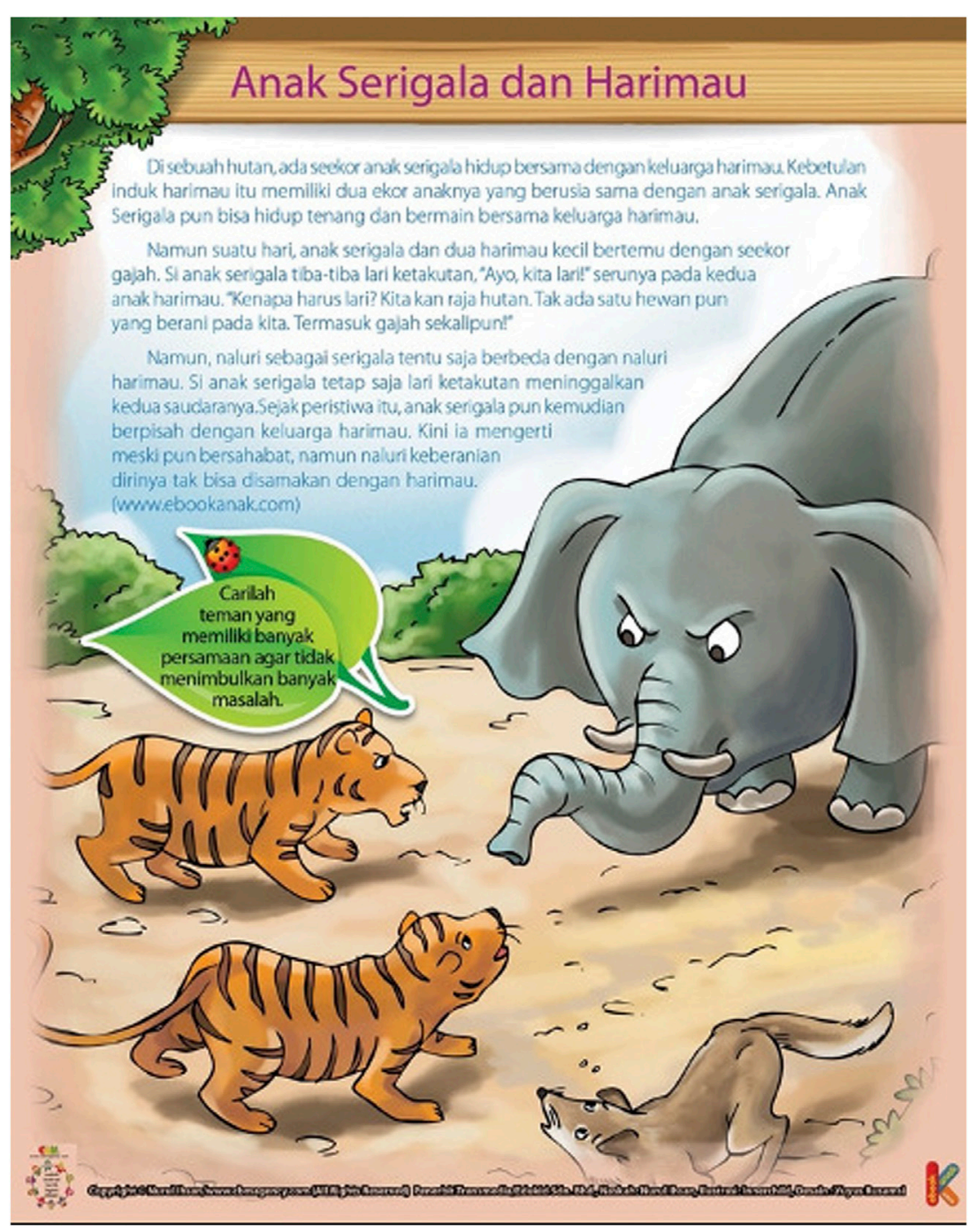

FIGURE 1 | The book of wolf and tiger cub.

Movies and books play an important role in giving examples and transmitting the value. Based on the interview and observation, some of the parents transform the value by telling story of animals from the book that they read before sleeping. Some parents said that the book that they always tell to their young children before going to sleep is "Anak Serigala and Harimau" or "wolf and tiger cub". The book tells the story about the peaceful lives of different animals in the jungle. There are wolves and tiger cubs and other animals. Then, there are elephants who come to the jungle and create a conflict as the elephants intend to rule the jungle. At the end, after discussion with the different animals, they can live together peacefully. The cover of the book that is always read is below.

Based on the Figure 1, the book of the wolf and tiger cub help to create a mindset of tolerance for young children. Tolerance means people can accept differences and make an agreement when there is difference. However. It is difficult to teach a real life tolerance to young children, and one of the ways for sharing the story of tolerance is using a book (Sufanti, et al., 2021). The book in Figure 1 is, based on the parent's opinion, able to help to create a mindset of tolerance because the book tells young children to live peacefully although they come from different backgrounds. In addition, Cigugur society is diverse and different in terms of religion. There are Muslims, Christians, Buddhists, Protestants, and others. The difference of religion in Cigugur sometimes lead to conflict and intolerance. Telling a story before going to sleep can engage the imagination, so that $\mathrm{t}$ will stay in their mind.

In addition, YouTube and other media sometimes show a positive and negative effect on teaching tolerance values for young children. Firstly, the content about sharing positive values can teach tolerance for children. For example, the channel "Dhar Mann" shows positive content in each video that is made. Parents and children discuss and analyze the 
video content on the YouTube and share the value that is seen from the video. As such, after discussing the content, the tolerance values can be transferred to the young children. The concept of analyzing video content helps to share young children's thoughts about tolerance. On the other hand, some negative content on YouTube cannot be avoided as well. Young children can access thousands of videos on YouTube, therefore parents should accompany when children watch the videos on YouTube.

Recognizing the difference in family will also show the character of tolerance for the children. This aims to be able to make children more confident and become children who appreciate every difference that exists. Usually, parents try to be able to give examples of these attitudes to their children when meeting someone from a different religion, or meeting in a different house of worship. At that time, parents explain to their children that every religion has its own place of worship, so this can make one continue to appreciate these differences.

"I always try to show children someone who has a different religion, both in terms of clothing, religion, houses of worship and others. So that apart from making children curious, this also makes them more open to differences." (TWK, Interview).

Respecting the difference either in the family or friends is one of the transformation methods of tolerance used by Cigugur society. Young children should be taught about respecting the difference in families in advance. For example, when young children meet with people in different religion, parents should teach them something which is respectful to them. Parents allow people in different religions to pray in different ways. Young children also should be taught that in this world, there are a lot of different beliefs with different praying practices. When it comes to the result from (Foley et al., 2020), they argue that introducing young children to differences can make them more tolerant. For example, when children come from a Muslim family, then are introduced to other relatives who are Christian or Buddhist. Let the young children make friends, discussing something and playing together. When they are friends, the tolerance values can be transformed automatically. Based on the results in Cigugur society, parents sometimes bring the young children to visit some different religious places of worship such as mosques, churches, and other places. In addition, Ospina and Medina (2020) believe that when young children are brought to some other members of family which have different backgrounds or different cultures, they will tend to be more tolerant so that they should have some respect towards the other religions.

Overall, although there are a lot of ways of transforming tolerance values towards young children, at the very least Cigugur society has ten ways of teaching tolerance. Each way of teaching tolerance has a good impact for the young children. However, although it can show the benefits of tolerance, the best practice is giving some positive examples by parents, since they only ones who are imitated by young children is the parents at that age.

\section{How do the Activities of the Transformation of Tolerance Values from Parents to Early Childhood Affect the Implementation of Tolerance Values?}

Tolerance is an attitude of openness and respect for differences between people (Maksum, 2015). Therefore, this is very important to be taught to the younger generation, especially in early childhood. Tolerance means respecting and learning from others, respecting differences, bridging cultural gaps, rejecting unfair stereotypes, finding common ground, and creating new bonds. Behavior that disrespects or hurts others, such as being cruel, bullying, or behavior that violates social rules (such as lying or stealing) should not be tolerated. Given that tolerance is a very important attitude, the Cigugur community has several activities and methods that can be taught to students when teaching tolerance. There are two activities for teaching tolerance to the others, namely teaching by listening to others, and giving some advice from parents.

The first activity that young children need to complete during tolerance value transformation is to be taught how to listen. In this case, parents need to teach young children about how to listen to others. Listening is a very important way to teach tolerance to the young children. They should be taught to listening to what people advise them. For example, when there is a religious speech, young children should be trying to learn from the speech delivered by religious leader.

"I always encourage my young children to listen to others. It is one of my ways for teaching tolerance to my son. Since listening can have a lot of advice, my son will learn so much from what people say" (TWK, Interview).

Based on the interview results, one of the parents believes that teaching listening to their young children can give a positive impact for improving tolerance values among young children. They can listen to the others since it will give them a lot of lessons. For example, when they meet an older person, young children can learn the experience, even though they are of different beliefs. Parents also said that they sometimes bring their young children to their grandmother and grandfather's house once a month, and usually young children get some advice about life and tolerance values. Although visiting their grandfather's house is rare, the advice from them would stick in young children mind's. Sometimes the tolerance values come from the advice that is obtained from them.

In addition, listening to the others can also help young children to be respectful of others. What is more, Manshur (2020) also believe that listening could also make students be open minded. Mansur undertook a study in "Pesantren" or an Islamic boarding school in Indonesia. Students in the school are always given the story of prophet particularly about tolerance, and it is done regularly. The results show that listening can have a good impact in teaching them to be tolerant.

There are five activities of transforming tolerance values based on the interview results in Cigugur society towards young 
children. Firstly, the family creates some activities to show young children that family is a glue between people who have different religions. In the activities, since Cigugur society has a lot of different religious backgrounds, family should be the place for conveying to the children that the world has different religions.

\section{"My young children are always taught about listening to others. It is because young children can be the people who are learning and listening. I never ban my young children from communicating or talking with other people who are from different religions" (TIU, Interview).}

Listening to others should be taught by a family since it becomes a glue of teaching and transforming the tolerance values towards others. In addition, when teaching and giving some advice to young children, parents need to emphasize that diversity cannot be avoided. In this world, people come from different religions, ethnicities, languages, races, and many others. When giving some advice, trying to say that the world is different is considered to be a good way. Showcasing differences should be one of the ways to make students understand the diversity in this world. Golebiowska (2020) believes that listening to different people who are of different race, religion, ethnicity, or language can make them more tolerant. In this research, young children are encouraged to make friends with someone who is different. In Cigugur society, some of the members of the family have different religious backgrounds. Then, when there is a gathering on a religious day such as Eid Mubarak or Christmas, they tend to create family gatherings in the home.

Thirdly, although some young children understand about the news and politics, it will be better to avoid political interest discussion in the family. The reason is that avoiding political discussion can lead to respect and peace, and transform tolerance. In this case, there are some other families who discuss politics at home and parents ask the children to follow parents' decisions during the election. While some children follow the parents' direction, some others decided not to follow parents' instruction in the general election. When parents and children have different points of view, then children will not respect them and tolerance values cannot be transmitted. Therefore, it will be better to avoid political interest and not discuss political interests during the election period. The interview with the parents' results show here that parents in Cigugur avoid discussing political interest.

"When my son asks me some questions after watching television about political interest, I try to answer in a general way without emphasizing each candidate. In my opinion, avoiding discussion about political interest can create life to be tolerant" (SRC, interview).

Based on the opinion from the parents, avoiding some political interest can be one of the ways of transforming tolerance values. It is because talking about politics can create a conflict, although it is in the family. Then, parents should also teach young children to have compassion for each other and respect for each other. Respecting others can be one of the activities of teaching tolerance. Wijaya Mulya et al. (2021) argue that there are two main benefits when families avoid political interest. Firstly, declining political interest in family can make them be more at peace. This is because sometimes children also have a choice, and when each member of family has different choice, it leads to the conflict. Secondly, avoiding political discussion can make family be more independent. In this case, each family member can have their choice and they just put the choice in the election box. Then, they can have any discussion after the election. In this study, although they are still young, parents need to teach young children not to discuss politics in the home since it leads to conflict.

In addition, giving some advice to children would be another benefit to transform tolerance values to young children. The advice is really important for young children since it will be another way of transforming tolerance. Usually, each week, parents give some advice to children about life. Based on the parents' opinion, the best time for giving some advice is before going to sleep. In this time, the advice will always be remembered by young children.

"I always try to give some advice to my young children, and the time for giving advice is before sleeping and when young children go to school. Even though the advice is only one sentence, it help young children to improve when they meet others" (YM, interview).

The advice from parents is really helpful for young children. Before going to sleep, parents should give some advice about life and help them to be tolerant. Advice from the parents mostly comes from the three types of advice above. For example, before going to sleep, parents give some advice about what have been done during the day. The study about getting some advice from parents has been undertaken by Rafferty and Beck (2020). They argue that the advice from parents has benefits for young children. Firstly, when the advice is given during a young age, it will become children's life principle. Based on the research, what parents do and say will probably be remembered by young children. This means that young children can follow parents' suggestions and remember some words when they are far away from their parents. For example, parents always give some advice for praying five times in Islam. Then, when children go far away, they will perhaps follow the advice for praying. Therefore, giving some advice can really help young children to be very importance.

\section{DISCUSSION}

Tolerance is an attitude towards respect the opinions or thoughts of others who have differences to us, and are able to help both fellow groups and different groups regardless of ethnicity, race, religion, and between groups (Sumadi, 2016). Another opinion says that tolerance is a behavior in which a person is able to accept differences of opinion and also activities that have been carried out without a debate or even causing conflict in the difference of opinion (Jati, 2014). Therefore, it can be said that when someone has an attitude of tolerance, they can provide great benefits to the surrounding environment. 
Tolerance requires a process of application and it takes a long time (Endang and Basri, 2015). The process can be carried out in a formal or non-formal educational environment. In the formal education process, the tolerance can be carried out in the school environment through school culture and classroom learning (Monteflor et al., 2006). Usually, the teacher conveys and gives examples of someone's tolerant attitude and intolerant behavior. The subject of Citizenship Education is one of the lessons that provides an explanation and understanding of tolerance (Banks, 2001; Schaller et al., 2007; Agus, 2013). In addition, in non-formal education, the transformation process of tolerance values is carried out in the community environment and also the family environment. The process of transforming the values of tolerance in the family environment is one way that parents can teach their children to have this attitude (Levina et al., 2016). Parents become people who have full responsibility in teaching their children to be tolerant. Based on the results of research conducted on the people of Cigugur, Kuningan, West Java, there are four values and several activities carried out by parents in transforming the values of tolerance towards early childhood.

The first and most important value to be transformed to early childhood is "Show respect for others". This is a value that aims to be able to respect and appreciate someone when meeting other people who are different. Parents in Cigugur, Kuningan, West Java have in common that respecting other people who are different from them is the most important thing that can be applied and taught to early childhood. They always bring their children to meet new people and talk to them, both from different religions and other backgrounds. By introducing children to people who have differences, it can allow children to interact and communicate with anyone, so that in the end the value of "respect for others" can be transformed. There are several similar studies on tolerance which say that the process of introducing children to other people who are different from them can lead to an attitude of tolerance. Sokol et al. (2021) argue that inviting children to meet other people has three main benefits. First, the child can easily adapt to a new environment, so the child will not have worries when they are away from their parents. Second, children who are often invited to meet other people and different religions can make it easier for them to find friends, so that they will not become introverts. Third, children who interact frequently can have a spirit of tolerance for differences. Sokol's opinion is reinforced by the results of research conducted by Mandayu (2020) which says that the process of forming the character of tolerance can be done by inviting children to get acquainted with other people, so that they can get to know a variety of different characters. In relation to the Cigugur community, parents also teach their children to be able to interact and adapt to new people so that their children can respect and appreciate other people who are different from them.

The second value and activity taught by parents in Cigugur is paying attention to children's books, toys and entertainment. Parents in Cigugur, Kuningan are very careful about the videos they watch on YouTube and the books they give their children before they go to sleep. Reading books and telling stories before bed has many benefits for early childhood. According to (Aslan and Aybek, 2020) books or stories that are conveyed to children before bed can provide a huge impact on the child's way of thinking. This can be something that children will always remember the next day after they wake up. In addition, videos or films that are watched by children can also shape their character, so parents need to be careful in giving books and watching movies that are always watched by their children. In the Cigugur community, parents teaching the values of tolerance always try to monitor the videos their children watch on YouTube. The film is always monitored through several restrictions contained on their cellphones, so they can easily see what movies their children watch. Second, books or stories that are told to their children before bed are also always considered, because this can be very influential on their mindset.

The third is recognizing and respecting differences in the family. This aims to be able to teach children that in a family there are several differences. In the context of the Cigugur community, every family has several religions, such as Christianity, Islam, and others. When both parents have different religious differences, then this becomes common in the Cigugur community. This is in accordance with the results of research conducted by Chávez Leyva (2021) which says that differences in family members need to be taught to their children, so that they are able to tolerate. When children are able to accept differences, especially religious differences, the process of transforming the values of tolerance has succeeded in being carried out for early childhood. Fourth is learning other cultures and traditions with children. Learning about the culture and traditions of other people is a very positive thing. By studying other cultures, children can see the difference between their daily activities and what they see in other people, so this can make children understand the differences that exist both in the surrounding environment and in different environments (Manshur, 2020). In the Cigugur community, parents always invite their children who are still at an early age to visit big cities, such as Jakarta, Cirebon, Bandung and others. When children are invited to a big city, they can know the differences and new cultures.

The four core tolerance values showed by parents in transforming tolerance can be said as part of a home educational experience. The concept of pedagogy of home is considered important for teaching tolerance from parents to young children. At home, parents are the teachers for their young children since they are taking care of everything for their children. This happens starting from when young children wake up until they are sleeping again. Here are some activities that parents can do during home pedagogies to transform tolerance values. Firstly, parents can control all activities that students do from waking up until they sleep again. They can play together, go out together and discuss something together and other activities. The quality time made by parents and young children will help young children to make parents their role model. Young children can probably follow the words that parents say and some characteristics of the parents. Secondly, the multicultural education at home can be transferred during the home pedagogies. In this part, parents can share the story telling, watching, and analysis of a movie together, read aloud a book for young children or go outside together or attend an event When there is something different in outside, parents can 
act as a dictionary for the young children. Thus, children would never interpret need answers from the internet about something they are curious about since parents can be their dictionary. It has been proven that home education can be considered important for young children to help them have tolerance values.

\section{CONCLUSION}

The transformation of tolerance values to early childhood is one of the most difficult things to do, and it requires a very long process. This is because teaching the value of tolerance just once or twice is not enough, it needs to be done continuously. In this case, although schools can teach positive things, parents have a very important role to be able to teach the values of tolerance to children in early childhood. The Cigugur community is an example in which the tolerance process can be transformed to their children, especially in early childhood. In the Cigugur community, one of the unique things is the families consisting of different religions. For example, a father is Muslim, while a mother is Christian and a son has different beliefs. However, even though they have different beliefs, the people of Cigugur can provide an example of the value of tolerance that is very beneficial for the Indonesian and international community. This is done by parents and becomes a very routine thing in each generation, so that they can live in harmony in their daily activities. In terms of maintaining harmony, there are several values and activities that are taught by parents to their children so that they are capable and have a spirit of tolerance, so that even though they live in an environment of different religions, they still live in harmony and side by side.

There are four main values conveyed and almost all parents in Cigugur apply and teach these values. These are showing respect for others, paying attention to children's books, toys, and entertainment, recognizing and respecting differences in the family and learning other cultures and traditions with children. Teaching children to be able to respect others is one of the most important values that needs to be taught in early childhood (Schweitzer and Sulzer-Azaroff, 1988; Heller and Hawkins, 1994; Godwin, et al., 2001; Avery, 2002; Brenick et al., 2019). Parents teach it by always making their children respect others. The second way is to monitor the books, movies, and videos they consume and what games the children are playing. The third is recognizing and respecting difference and the last is learning other cultures and traditions with children.

Apart from the positive impact of the study, there are some limitations to this study. Firstly, the Hawthorne effect might be happened during the observation. This is because, during the observation of some families, they are aware that parents are under observation, so that they might change their habit or show very positive values that they hold. Secondly, during the interviews, there were some parents whose children are not young anymore since there were a few parents who are raising their young children at the moment. Thus, they answer the questions based on their experience as parents raising their child in the past. Thirdly, the Cigugur society is far away from the city, and the access to that community is difficult. Therefore, a long time is needed to develop and understand clearly about the study.

In regards to the transforming tolerance values, further study can be undertaken in Cigugur as it would be interesting to be studied by other research. Here are some suggestions for future study that might be done for the field of tolerance. First, it might be interesting to see and observe closely about home educational experience or home pedagogy in a family who have different religions. Each religion has different religious practices and the way of teaching children is different as well, so how they raise and educate characteristics of tolerance in the family might be interesting to be observed. In addition, there are a public school and boarding school in the Cigugur community. It might also be interesting to see the school perspective and school program in the Cigugur community on teaching tolerance values toward their students. After understanding the overall tolerance values that have been taught in this study, it might also be interesting to have a closer look at "moving beyond tolerance". This means how parents can teach respect to young children, especially respecting differences since Cigugur society has a lot of difference, particularly the difference in religion. Therefore, it would be beneficial for other researchers and further study in the field of tolerance.

\section{DATA AVAILABILITY STATEMENT}

The data that support the findings of this study are available on request from the corresponding author, TS. The data are not publicly available due to restrictions e.g., their containing information that could compromise the privacy of research participants.

\section{ETHICS STATEMENT}

The studies involving human participants were reviewed and approved by the LPPM Universitas Negeri Jakarta. The patients/ participants provided their written informed consent to participate in this study.

\section{AUTHOR CONTRIBUTIONS}

TS, FA, and AC contributed to the design and implementation of the research, to the analysis of the results and to the writing of the manuscript.

\section{ACKNOWLEDGMENTS}

Thanks to the Rector of Universitas Negeri Jakarta, Dean of the Faculty of Social Sciences, and the Coordinator of the Pancasila and Citizenship Education Study Program for providing funding and permission to conduct this research. Thanks also go to the Cigugur District Leadership Board, the Head of Cigugur Village, and all Cigugur Village residents. They have assisted, both morally and materially, for the implementation of this research. 


\section{REFERENCES}

Agus, S. (2013). The Role of Citizenship Education in Fostering Student Attitudes Tolerance. Medan: Journal of Government Science and Social Politics.

Alzyoud, M. S., Khaddam, A. F., and Al-Ali, A. S. (2016). The impact of teaching tolerance on students in jordanian schools. J. Humanities Soc. Sci. $15,1$.

Aslan, S., and Aybek, B. (2020). Testing the Effectiveness of Interdisciplinary Curriculum-Based Multicultural Education on Tolerance and Critical Thinking Skill. Int. J. Ed. Meth 6 (1), 43-55. doi:10.12973/ijem.6.1.43

Avery, P. G. (2002). Teaching tolerance: what research tells us.(Research and Practice). Soc. Edu. 66 (5), 270-276.

Banks, J. A. (2001). Citizenship Education and Diversity. J. Teach. Educ. 52 (1), 5-16. doi:10.1177/0022487101052001002

Beckwith, F. J., and Koukl, G. (1998). Relativism: Feet firmly planted in mid-air. Ada, Michigan: Baker Books.

Bernal, D. D. (2001). Learning and living pedagogies of the home: The mestiza consciousness of Chicana students. Int. J. Qual. Stud. Edu. 14 (5), 623-639. doi:10.1080/09518390110059838

Brenick, A., Lawrence, S. E., Carvalheiro, D., and Berger, R. (2019). Teaching tolerance or acting tolerant? Evaluating skills- and contact-based prejudice reduction interventions among Palestinian-Israeli and Jewish-Israeli youth. J. Sch. Psychol. 75, 8-26. doi:10.1016/j.jsp.2019.07.001

Chávez Leyva, Y. (2021). "Behind each beautiful painting is a child longing to be free": Deep visual listening and children's art during times of crisis. Glob. Stud. Child. 11 (2), 123-141. doi:10.1177/20436106211023509

Endang, B. (2015). Developing Tolerance and Togetherness Attitudes among Students. J. Educ. Sci. Vis. 3, 2015. number 03 of Yogyakarta.

Foley, T., Dinan-Thompson, M., and Caltabiano, N. (2020). Interreligious learning and teaching: Unfolding layers of meaning in lived experience to inform possibilities for students in Catholic schools. J. Relig. Educ. 68 (2), 141-160. doi:10.1007/s40839-020-00099-2

Gilliard, J. L., and Moore, R. A. (2007). An Investigation of How Culture Shapes Curriculum in Early Care and Edocation Programs on a Native American Indian Reservation. Early Child. Edu. J. 34, 4. June 2007 New York. doi:10.1007/ s10643-006-0136-5

Godwin, K., Ausbrooks, C., and Martinez, V. (2001). Teaching tolerance in public and private schools. Phi Delta Kappan 82 (7), 542-546. doi:10.1177/ 003172170108200713

Golebiowska, E. A. (2020). The mechanisms behind the relationship between education and political tolerance. Polit. Groups, Identities 8 (5), 937-956. doi:10.1080/21565503.2019.1624179

Halimah, L., Arifin, R. R. M., Yuliariatiningsih, M. S., Abdillah, F., and Sutini, A. (2020). Storytelling through "Wayang Golek" puppet show: Practical ways in incorporating character education in early childhood. Cogent Edu. 7 (1), 1794495. doi:10.1080/2331186x.2020.1794495

Heller, C., and Hawkins, J. A. (1994). Teaching Tolerance: Notes from the Front Line. Teach. Coll. Rec. 95 (3), 337-368.

Hong, Y. (2003). “An Ethnographic Study of Korean Kindergartners' Reasoning During Group Moral Discussions," in Earlly Childhood Education Journal (New York: Syracuse). Vol. 30, December 3, 2003. doi:10.1023/a:1022009804884

Huber, N. (2003). An experiential leadership approach for teaching tolerance for ambiguity. J. Edu. Business 79 (1), 52-55. doi:10.1080/08832320309599088

Jati, W. R. (2014). Religious Tolerance in Multiculturalism Education Sang Timur Catholic High School Students Yogyakarta. Yogyakarta: Journal of Educational Horizon.

Kwok, P. (2004). Examination-oriented knowledge and value transformation in East Asian cram schools. Asia Pac. Educ. Rev. 5 (1), 64-75. doi:10.1007/ bf03026280

Lehtonen, M. (2019). The Development of Religious Tolerance: Co-operative Board Games with Children and Adolescents. IATL Reinvention: Int. J. Undergraduate Res. 2 (2). Retrieved from https://warwick.ac.uk/fac/cross fac/iatl/reinvention/archive/volume2issue2/lehtonen/.

Levina, L., Lukmanova, O., Romanovskaya, L., and Shutova, T. (2016). Teaching Tolerance in the English Language Classroom. Proced. - Soc. Behav. Sci. 236, 277-282. doi:10.1016/j.sbspro.2016.12.029
Lintner, T. (2005). A world of difference: Teaching tolerance through photographs in elementary school. Soc. Stud. 96 (1), 34-37. doi:10.3200/tsss.96.1.34-37

Maine, F., and Čermáková, A. (2021). Using linguistic ethnography as a tool to analyse dialogic teaching in upper primary classrooms. Learn. Cult. Soc. Interaction 29, 100500. doi:10.1016/j.lcsi.2021.100500

Maksum, Ali. (2015). Model of Tolerance Education in Modern and Salaf Islamic Boarding Schools. J. Islamic Religious Edu. Vol. 03, 1, 2015. Surabaya.

Mandayu, Y. Y. B. (2020). Pembentukan Karakter Toleransi Melalui Habituasi Sekolah. J. Pend. Il. Peng. Sos. Ind. 5 (2), 31-33. doi:10.1007/978-3-3197869210.26737/jpipsi.v5i2.1598

Manshur, F. (2020). Typical Literary Works of Pesantren on Righteousness Teaching within Cultural Transformation. J. Soc. Stud. Edu. Res. 11 (4), 114-148.

Monteflor, M. O., Williams, A. R., and Williams, P. D. (2006). Parent Motivation Strategies and the Performance of Preschoolers in a Rural Philippine Municipality. Early Child. Edu. J. 33, 5. Summer 2006. New York. doi:10.1007/s10643-005-0035-1

Musyafiq, A. (2019). The Cultivation of Tolerance Value in Madrasah through Tahfidh Hadits. Nadwa 12 (2), 243. doi:10.21580/nw.2018.12.2.2938

Nurasiah, A., and Munira, W. (2019). The Correlation between: Awareness of History, Religious Values and Multiethnic Understanding with Tolerance Attitude. Paramita: Hist. Stud. J. 29 (1), 10-17. http://journal.unnes.ac.id/nju/.

Ospina, N. S., and Medina, S. L. (2020). Living and Teaching Internationally: Teachers Talk about Personal Experiences, Benefits, and Challenges. Jnl Res. Internatl Edu. 19 (1), 38-53. doi:10.1177/1475240920915013

Rafferty, K. A., and Beck, G. A. (2020). "You Are Not Alone": Advice Giving for Parents of Children Living with Complex Chronic Conditions. Health Commun. 35 (11), 1386-1395. doi:10.1080/10410236.2019.1636341

Rapp, C., and Freitag, M. (2015). Teaching tolerance? Associational diversity and tolerance formation. Polit. Stud. 63 (5), 1031-1051. doi:10.1111/14679248.12142

Sari, E. R., Haviz, M., and Afwadi, A. (2017). Model Toleransi Pada Pembelajaran Sains Kelas Viii Semester Ii Di Smp Pesantren Pramuka Alhira Padang Panjang. Biosfer: Jurnal Pendidikan Biologi 10 (1), 22-31.

Schaller, A., Rocha, L. O., and Barhinger, D. (2007). Maternal Attitudes and Parent Education: How Immigrant Mother Support Their Child's Education Despite Their Own Low Level of Education. Early Child. Edu. J. 34, 5. June 2007 New York: Springer Science + Business Media Inc. doi:10.1007/s10643-006-0143-6

Schweitzer, J. B., and Sulzer-Azaroff, B. (1988). Self-control: teaching tolerance for delay in impulsive children. J. Exp. Anal. Behav. 50 (2), 173-186. doi:10.1901/ jeab.1988.50-173

Sokol, M., Galyna, R., Khrystyna, S., Hvozdyak, O., Violetta, G., and Svitlana, I. (2021). Tolerance in the Communicative Culture of Modern Educational Manager. $P y R 9$ (SPE3), 1170. doi:10.20511/pyr2021.v9nspe3.1170

Sufanti, M., Nuryatin, A., Rohman, F., and J. Waluyo, H. (2021). The Content of Tolerance Education in Short Story Learning in High Schools. Ajue 17 (1) 112-123. doi:10.24191/ajue.v17i1.12609

Sumadi, T. (2017). Transforming Social Values to Young Children through Games. Jakarta: Faculty of Social Sciences, Jakarta State University.

Sumadi, T. (2016). Transforming the Values of Social Competence to Early Childhood. Jakarta: Dissertation, Postgraduate Program, State University of Jakarta.

Sumadi, T., Yetti, E., Yufiarti, Y., and Wuryani, W. (2019). Transformation of Tolerance Values (in Religion) in Early Childhood Education. jpud 13 (2), 386-400. doi:10.21009/JPUD.132.13

Tas, H., and Minaz, M. B. (2019). The Impact of Biography-Based Values School Students' Attitudes towards Tolerance Value. Int. J. Progressive Edu. 15 (2), $118-139$.

Tican, C. (2020). Investigation of Pre-service Teachers' Tolerance Tendencies and Democratic Tendencies. Ies 13 (11), 20-32. doi:10.5539/ies.v13n11p20

Utomo, C., and Wasino, W. (2020). An Integrated Teaching Tolerance in Learning History of Indonesian National Movement at Higher Education. J. Soc. Stud. Edu. Res. 11 (3), 65-108.

Wijaya Mulya, T., Aditomo, A., and Suryani, A. (2021). On being a religiously tolerant Muslim: discursive contestations among pre-service teachers in contemporary Indonesia. Br. J. Religious Edu., 1-14. doi:10.1080/ 01416200.2021 .1917338 
Wiryawan, S. A. (2016). Education for Early Childhood. Yogyakarta: Social Agency Press.

Yin, R. K. (2017). Case study research and applications: Design and methods. Los Angeles: SAGE Publications.

Conflict of Interest: The authors declare that the research was conducted in the absence of any commercial or financial relationships that could be construed as a potential conflict of interest.

Publisher's Note: All claims expressed in this article are solely those of the authors and do not necessarily represent those of their affiliated organizations, or those of the publisher, the editors and the reviewers. Any product that may be evaluated in this article, or claim that may be made by its manufacturer, is not guaranteed or endorsed by the publisher.

Copyright $\odot 2021$ Sumadi, Abdillah and Casmana. This is an open-access article distributed under the terms of the Creative Commons Attribution License (CC BY). The use, distribution or reproduction in other forums is permitted, provided the original author(s) and the copyright owner(s) are credited and that the original publication in this journal is cited, in accordance with accepted academic practice. No use, distribution or reproduction is permitted which does not comply with these terms. 